\title{
Challenges in Online Marketing of Dry Chilli in Selected APMC of Karnataka, India
}

\author{
K. Pavithra and Mahantesh R. Nayak* \\ Deportment of Agricultural Economics, College of Agriculture, University of Agricultural \\ Sciences, Dharwad-580005, Karnataka, India \\ *Corresponding author
}

\section{Keywords}

Online marketing, ReMS, UMP

\section{Article Info}

Accepted: 04 December 2018 Available Online: 10 January 2019

\section{A B S T R A C T}

In traditional method of agricultural marketing farmers were exploited by the middlemen by taking major share in the consumer's price. In view of multiple benefits of online trading, the farmers in Karnataka were taking their business online, because of Unified Marketing Platform (UMP) an initiative by the state govt. launched in 2014 by the Rashtriya e-market services (ReMS). The present study attempts to assess the challenges in online marketing of dry chilli in Hubballi Agricultural Produce Market Committee, 60 online dry chilli farmers, 10 online traders, 10 Commission agents and market Committee were selected. The Garrett Ranking technique and Likert's scale used to measure severity and ranking the constraints. Major constraints faced by farmers in online marketing were farmer's outstanding loan in financial institution followed by lack of knowledge regarding complete information of e-payment. Major challenges faced by traders in online marketing were lack of funds for daily transactions followed by lack of loan facility for the immediate payments to the farmers. Constraints faced by market committee in online agricultural marketing were poor participation of farmers followed by limited infrastructure.Online agricultural marketing was initiated only in six APMCs of North Karnataka on pilot basis. The infrastructure for post-harvest management needs to be strengthened, particularly cold storage, cleaning and grading infrastructure at primary level on public-private partnership mode. There is an urgent need for capacity building programmes by the state government and other line organizations to train the employees/staffs of APMCs. There is need to create awareness about online marketing through training, campaignsand other extension activities to farmers.

\section{Introduction}

Agriculture sector accounts for 14 per cent of India's GDP (2017-18) and employed around 50 per cent of the country's workforce in agriculture. In traditional method of agricultural marketing farmers were exploited by the middlemen by taking major share in the consumer's price. In view of multiple benefits of online trading, the farmers in Karnataka were taking their business online, because of Unified Marketing Platform (UMP) an initiative by the state govt. launched in 2014 by the Rashtriya e-market services (ReMS). In Karnataka online platforms are established in 55 APMCs (Agricultural Produce Market Committee). It facilitates the interaction between traders and 
farmers. UMP has managed to eliminate middlemen. Karnataka's online marketing for farmers. Similarly, The Government of India recommending it to other states coming forward to adopt it now. Other states like Orissa, Rajasthan, Tamil Nadu, Gujarat and Uttar Pradesh were also interested in replicating the Karnataka model. Promoting the idea of "My produce and my price", ReMS has been training farmers through elected members of APMC in using the online marketing system for their produce. Chilli is the universal spice or Spice of India. Chilli is nature's wonder. Indian chili and its products exporting to countries like Sri Lanka, Bangladesh, Saudi Arabia and USA for dry chilli. Similarly, Oleoresin is exported to USA, Germany, Japan, United Kingdom and France. Dry chilli is being a high commercial value crop domestically and internationally, it needs online marketing throughout the country. Online trading of the agriculture commodities is the recent introduced policy intervention by the Govt. of Karnataka. There are many Challenges in implementing this policy initiative. Even though online marketing is cost effective, convenient, improves relationship between traders and farmers. But,it has facing unique challenges like marketing integration, post-harvest management,security and privacy for traders, lack of confidence among the farmers, lack of awareness due to illiteracy etc., it needs to becreate strongly awareness to farmers are facing marketing of their produce.

To identify the challenges involved in online agricultural marketing of dry chilli and examine their severity.

\section{Materials and Methods}

The study is mainly based on primary data for achieving objective. The study area comprises of Hubballi Agricultural Produce Market Committee (APMC). The primary data were collected by using pretested schedule from sample respondents. The data were mainly contain constraints of online marketing and severity of the constraints in online marketing, all those information collected from online farmers, traders, market intermediaries and market committee. The personal interview method was used to collect data from respondents, while it ensured that data made available by farmers, traders was precise and relevant.

Garrett's ranking technique was used to find out the most significant factor which influences the respondent. As per the method, respondents had been asked to assign the rank for all factors and the outcome of such ranking has been converted into score value with the help of the following formula:

Percent position $=100\left(\mathrm{R}_{\mathrm{ij}}-0.5\right) / \mathrm{N}_{\mathrm{j}}$

Where

$R_{i j}=$ Rank given for the $i^{\text {th }}$ variable by $j^{\text {th }}$ respondents

$\mathrm{N}_{\mathrm{j}}=$ Number of variable ranked by $\mathrm{j}^{\text {th }}$ respondents

With the help of Garrett's table, the per cent position estimated is converted into scores. Then for each factor, the scores of each individual are added and then total value of scores and mean values of score is calculated. The factors having highest mean value is considered to be the most important factor.

In this study, measurement of severity of constraints was also considered. Likert's scale was used to measure the severity of challenges faced by farmers, traders and commission agents.

\section{Likert's scale}

\begin{tabular}{|l|l|}
\hline Category & Score \\
\hline Most severe & 4 \\
\hline Severe & 3 \\
\hline Moderate & 2 \\
\hline Low & 1 \\
\hline
\end{tabular}




\section{Results and Discussion}

\section{Challenges faced by farmers to go for online agricultural marketing}

The challenges faced by farmers to go for online agricultural marketing had been ranked using Garrett's ranking technique as represented in Table 1. Most of online farmers had reported that farmer's outstanding loan in financial institution is the major problem and ranked first with mean score of 79.48 followed by illiteracy of farmers, lack of knowledge of e payment and difficulty of e- payment to small farmer with mean score of 75.56, 67.90 and 55.26 respectively. Unavailability of pan cards and financial help taken by middleman were ranked least with mean score of 27.40 and 25.43 respectively.

Results revealed that, major challenges faced by farmers in online agricultural marketing were farmer's outstanding loan in financial institution. In online marketing the traded value was directly credited to farmer's bank account and it might be the reason for farmers to fear about e-payment. The other challenges faced in that order were lack of knowledge regarding complete information of e-payment, lack of banking awareness, lack of interest, unawareness of ATM operation, lack of confidence and lack of usage of mobile phone by farmers because of the illiteracy of farmers, lack of training and lack of awareness creating programmes about online trading.

Sumitaand Kirubakaran (2014) observed similar challenges in the study on Eagriculture information management system, researcher concluded that majority of farmers in the state or country were not aware that mobile phones and internet could be used to conduct businesses and receive information. Illiteracy among farmers in reading message was also another factors pertained to the nonusage of technology in agriculture.

\section{Severity of challenges faced by farmers to go for online agricultural marketing}

Challenges were further analyzed according to their severity based on their mean values as; 0-1 less severe, 1-2 moderate, 2-3 severe, 3-4 most severe, data were analyzed using SPSS 11.0 . Out of fifteen challenges, seven were measured as most severe, seven were severe and one was considered as moderate. Based on SD (Standard deviation) value firmness or degree of variability of challenges were measured. As a whole the challenges were perceived as "severe" with Mean $=2.80$ and SD $=0.62$ are presented in the Table 2 .

Farmers were faced seven most severe problems, they were farmer's outstanding loan in financial institution, illiteracy of farmers, lack of knowledge, lack of immediate payment, lack of banking awareness, more difficulty to small farmers and leased cultivators. Online marketing was recent policy of Govt. towards cashless transactions. Hence, farmers didn't have awareness about online trading, small and marginal farmers needed cash immediately after trading. Online trading was problematic to leased land cultivators, because they didn't have land ownership certificate for registration in online trading portal (ReMS). Lack of usage of mobile phone, lack of interest, unawareness of ATM operation, complex banking procedure, unavailability of pan card and financial help taken by middlemen were the severe problems. Because majority of farmers were illiterate and they were unaware about new technologies of banking and marketing and also farmers had taken financial help from middlemen for cultivation practices and they need to pay back, it was not possible in epayment. Lack of confidence and long term 
relationship with trader were moderate problems.

Harjot and Daljit (2015) observed similar challenges in e-commerce in India, where in lack of skills, security problems, people didn't yet sufficiently trust paperless, faceless transactions, Majority of farmers didn't know how to use internet and they preferred traditional approach of marketing.

\section{Challenges faced by traders in online agricultural marketing}

Table 3 represents the challenges of online agricultural marketing faced by traders. These challenges were analyzed by using Garrett ranking technique. Lack of funds for daily transaction, lack of proper grading, diversion to traditional market owing to problems in online market were the top three problems in online agricultural marketing of drychilli with mean score of $64.4,59.3$ and 58.3 respectively. Poor quality of produce, more GST and more high storage cost were less problematic with mean score $42.5,41.3$ and 29.5 respectively. Because traders need to pay traded amount directly to farmers bank account within 24 hours of transaction, for this traders were facing a problem of sufficient funds for immediate e-payment and farmers poorly participated in online marketing and divert towards traditional market because lack of confidence about epayment. Other problems were high transport and labor cost. More official formalities, poor quality of produce, more GST and high storage cost because of which market margin appropriated by traders was very reasonable or even functioned at loss in online trading.

\section{Severity of challenges faced by traders in online agricultural marketing}

Table 4 shows severity of challenges of traders in online marketing. Out of twelve challenges, four were considered as most severe, six were severe and two were considered as moderate. Based on SD (Standard deviation) value firmness or degree of variability of challenge was measured. Overall challenges were measured as "severe" with mean=2.7 and $\mathrm{SD}=0.93$. There were four most severe challenges as lack of e-payment, diversion to traditional markets owing to problems in online marketing, lack of proper grading and more official formalities. Some other severe challenges were inadequate loan facility for trader, lengthy banking procedure for e-payment, high transportation and labor cost, poor quality of produce, poor arrivals and heavy competition of traders in online trading. More GST and storage cost were moderate problems that resulted to low market margin.

These findings were in consonance with Rahul (2008), who studied challenges in adoption of e- commerce in agribusiness and found them as technical and Govt. policies (band width, free movement of goods across the state, market and trade policies), legal frameworks etc, The socio cultural diversity, low literacy and regional language problems make the task more difficult.

\section{Challenges faced by commission agents in online agricultural marketing}

Table 5 represents the challenges faced by commission agents in online marketing of dry chilli. Challenges were ranked by using Garrett ranking. Most of the agents faced problems like, lack of proper grading and diversion to traditional market owning to problems in online markets as major problems with mean score of 70.8 and 70.0 respectively. More GST and high labor charges were the least problems with 38.4 and 37.6 respectively. Because online trading of agricultural produce was initiated only in few markets of Karnataka, farmers strongly believed in traditional marketing and poorly participated in online marketing. Other 
problems were limited grading facility in APMCs, more GST and High labour cost.

\section{Severity of challenges faced by commission agents in online agricultural marketing}

Severity of challenges was measured by using mean and SD. Four challenges were considered as most severe, three were severe and two were measured as moderate. Overall challenges were measured as "severe" with the mean value 2.19 and standard deviation 0.91 as represented in Table 6.It revealed that severity of challenges faced by commission agents in online marketing as lack of proper grading, diversion to traditional market owing to problems in online markets, difficulty to e- payment for small and marginal transactions and more official formalities. Fear about income tax, laborious task of e- payment and high variability in quality of produce were severe problems. More GST and high labour cost were moderate problems, because of high cost and poor quality of produce and lack of grading, it affected to commission charges appropriated by commission agents.

These findings were conformity with the findings of Amrathraj (2014), who observed that challenges faced by market intermediaries were poor arrivals, low turnover followed by quality challenges, seasonality of arrivals and wastages of produce during loading and unloading.

Table.1 Challenges faced by the farmers to go for online marketing $(n=60)$

\begin{tabular}{|c|l|c|c|}
\hline SI. No. & \multicolumn{1}{|c|}{ Challenges } & Garrett Mean Score & Ranks \\
\hline $\mathbf{1}$ & Farmer's outstanding loans in financial institution & 79.48 & I \\
\hline $\mathbf{2 .}$ & Illiteracy of farmers & 75.56 & II \\
\hline $\mathbf{3}$ & $\begin{array}{l}\text { Lack of knowledge regarding the complete information of E } \\
\text { payment }\end{array}$ & 67.90 & III \\
\hline $\mathbf{4}$ & More difficulty of e-payment for small farmer & 55.26 & IV \\
\hline $\mathbf{5}$ & Lack of immediate payment & 54.53 & V \\
\hline $\mathbf{6}$ & Lack of banking awareness & 52.41 & VI \\
\hline $\mathbf{7}$ & Lack of interest in online marketing & 50.68 & VII \\
\hline $\mathbf{8}$ & Unawareness of ATM operation & 47.96 & VIII \\
\hline $\mathbf{9}$ & Lack of confidence in online marketing & 45.46 & IX \\
\hline $\mathbf{1 0}$ & Complex procedure of banking operation & 45.18 & X \\
\hline $\mathbf{1 1}$ & e-payment problematic to leased land cultivators & 44.16 & XI \\
\hline $\mathbf{1 2}$ & Lack of usage of mobile phone & 41.80 & XII \\
\hline $\mathbf{1 3}$ & Long term relationship with trader & 37.50 & XIII \\
\hline $\mathbf{1 4}$ & Unavailability of PAN cards with farmers & 27.40 & XIV \\
\hline $\mathbf{1 5}$ & Financial help taken by the middlemen & 25.43 & XV \\
\hline
\end{tabular}


Table.2 Severity of challenges of farmers in online marketing $(n=60)$

\begin{tabular}{|c|l|c|c|}
\hline $\begin{array}{c}\text { SI. } \\
\text { No. }\end{array}$ & \multicolumn{1}{|c|}{ Challenges } & Mean & SD \\
\hline $\mathbf{1}$ & Farmer's outstanding loans in financial institution & 3.95 & 0.22 \\
\hline $\mathbf{2 .}$ & Illiteracy of farmers & 3.80 & 0.35 \\
\hline $\mathbf{3}$ & Lack of banking awareness & 3.95 & 0.67 \\
\hline $\mathbf{4}$ & More difficulty of e-payment for small farmer & 3.85 & 0.36 \\
\hline $\mathbf{5}$ & Lack of knowledge regarding the complete & 3.23 & 0.62 \\
\hline & information of E payment & & 0.40 \\
\hline $\mathbf{6}$ & Lack of immediate payment & 3.06 & 0.58 \\
\hline $\mathbf{7}$ & e-payment is problematic to leased land cultivators & 3.41 & 0.68 \\
\hline $\mathbf{8}$ & Lack of interest in online marketing & 2.70 & 0.80 \\
\hline $\mathbf{9}$ & Unawareness of ATM operation & 2.58 & 0.67 \\
\hline $\mathbf{1 0}$ & Complex procedure of banking operation & 2.40 & 0.87 \\
\hline $\mathbf{1 1}$ & Lack of usage of mobile phone & 2.80 & 0.77 \\
\hline $\mathbf{1 2}$ & Unavailability of PAN cards with farmers & 2.06 & 0.67 \\
\hline $\mathbf{1 3}$ & Financial help taken by the Middlemen & 2.56 & 1.08 \\
\hline $\mathbf{1 4}$ & Long term relationship with trader & 1.68 & 0.64 \\
\hline $\mathbf{1 5}$ & Lack of confidence in online marketing & 1.28 & 0.62 \\
\hline & overall & 2.80 & \\
\hline
\end{tabular}

Note: SD- Standard Deviation

Table. 3 Challenges faced by traders in online marketing $(n=10)$

\begin{tabular}{|c|l|c|c|}
\hline SI. No. & \multicolumn{1}{|c|}{ Challenges } & $\begin{array}{c}\text { Garrett Mean } \\
\text { score }\end{array}$ & Ranks \\
\hline 1. & Lack of funds for daily transaction & 64.4 & I \\
\hline 2. & Lack of proper grading & 59.3 & II \\
\hline 3. & $\begin{array}{l}\text { Diversion to traditional market owing to } \\
\text { problems in online market }\end{array}$ & 58.3 & III \\
\hline 4. & Poor arrivals for online marketing & 56.3 & IV \\
\hline $\mathbf{5 .}$ & Inadequacy of loan facilities & 54.5 & V \\
\hline 6. & Lengthy banking procedure & 50.7 & VI \\
\hline 7. & Heavy competition among traders & 56.6 & VII \\
\hline $\mathbf{8 .}$ & High transportation cost and labour cost & 46.5 & VIII \\
\hline 9. & More official formalities & 46.2 & IX \\
\hline $\mathbf{1 0 .}$ & Poor quality of the produce & 42.5 & X \\
\hline $\mathbf{1 1 .}$ & More GST & 41.3 & XI \\
\hline $\mathbf{1 2 .}$ & High storage cost & 29.5 & XII \\
\hline
\end{tabular}


Table.4 Severity of challenges of traders in online marketing $(n=10)$

\begin{tabular}{|c|l|c|c|}
\hline S. No. & \multicolumn{1}{|c|}{ Challenges } & Mean & SD \\
\hline 1. & Lack of funds for daily transactions & 3.7 & 0.94 \\
\hline 2. & Lack of proper grading & 3.4 & 0.96 \\
\hline $\mathbf{3 .}$ & $\begin{array}{l}\text { Diversion to traditional market owing to } \\
\text { problems in online market }\end{array}$ & 3.7 & 0.94 \\
\hline $\mathbf{4 .}$ & More official formalities & 3.2 & 1.03 \\
\hline $\mathbf{5 .}$ & Heavy competition among traders & 2.9 & 1.10 \\
\hline $\mathbf{6 .}$ & Poor arrivals for online marketing & 2.8 & 0.91 \\
\hline $\mathbf{7 .}$ & Inadequacy of loan facilities & 2.7 & 1.05 \\
\hline $\mathbf{8 .}$ & Poor quality of the produce & 2.6 & 0.69 \\
\hline $\mathbf{9 .}$ & Lengthy banking procedure & 2.4 & 1.07 \\
\hline $\mathbf{1 0 .}$ & High transportation cost and labour cost & 2.0 & 0.81 \\
\hline $\mathbf{1 1 .}$ & More GST & 1.9 & 0.99 \\
\hline $\mathbf{1 2 .}$ & High storage cost & 1.4 & 0.69 \\
\hline & Overall & 2.7 & 0.93 \\
\hline
\end{tabular}

Note: SD- Standard Deviation

Table.5 Challenges faced by commission agents in online marketing $(n=10)$

\begin{tabular}{|c|l|c|c|}
\hline SI. No. & \multicolumn{1}{|c}{ Challenges } & $\begin{array}{c}\text { Garrett Mean } \\
\text { Score }\end{array}$ & Ranks \\
\hline $\mathbf{1}$ & Lack of proper grading & 70.8 & I \\
\hline $\mathbf{2}$ & $\begin{array}{l}\text { Diversion to traditional market owing to } \\
\text { problems in online market }\end{array}$ & 70.0 & II \\
\hline $\mathbf{3}$ & $\begin{array}{l}\text { Difficulty to e-payment for Small and marginal } \\
\text { farmers transactions }\end{array}$ & 64.4 & III \\
\hline $\mathbf{4}$ & More official formalities & 55.7 & IV \\
\hline $\mathbf{5}$ & Fear about income tax & 53.5 & V \\
\hline $\mathbf{6}$ & Laborious task of e-payment & 43.2 & VI \\
\hline $\mathbf{7}$ & High variability in quality of the produce & 41.3 & VII \\
\hline $\mathbf{8}$ & More GST & 38.4 & VIII \\
\hline $\mathbf{9}$ & High labour cost & 37.6 & IX \\
\hline
\end{tabular}


Table.6 Severity of challenges of commission agents in online marketing $(n=10)$

\begin{tabular}{|c|l|c|c|}
\hline Sl. No. & \multicolumn{1}{|c|}{ Challenges } & Mean & SD \\
\hline $\mathbf{1}$ & Lack of proper grading & 3.6 & 0.84 \\
\hline $\mathbf{2}$ & $\begin{array}{l}\text { Diversion to traditional market owing to } \\
\text { problems in online market }\end{array}$ & 3.7 & 0.67 \\
\hline $\mathbf{3}$ & $\begin{array}{l}\text { Difficulty to e-payment for Small and } \\
\text { Marginal transactions }\end{array}$ & 3.1 & 0.87 \\
\hline $\mathbf{4}$ & More official formalities & 3.1 & 0.99 \\
\hline $\mathbf{5}$ & Fear about income tax & 2.3 & 0.94 \\
\hline $\mathbf{6}$ & Laborious task of e-payment & 2.1 & 0.94 \\
\hline $\mathbf{7}$ & High variability in quality of the produce & 2.2 & 0.91 \\
\hline $\mathbf{8}$ & More GST & 1.6 & 0.99 \\
\hline $\mathbf{9}$ & High labor cost & 1.9 & 0.91 \\
\hline & Overall & 2.1 & 0.99 \\
\hline
\end{tabular}

Note: SD- Standard Deviation

Table.7 Challenges faced by market committee regarding online marketing

\begin{tabular}{|c|l|c|}
\hline SI. No. & \multicolumn{1}{|c|}{ Challenges } & Rank \\
\hline $\mathbf{1}$ & Poor farmer participation & I \\
\hline $\mathbf{2}$ & Limited of infrastructure (Grading storage) & II \\
\hline $\mathbf{3}$ & Limited quantity of lots & III \\
\hline $\mathbf{4}$ & Inadequate knowledge of e-payment & IV \\
\hline $\mathbf{5}$ & Poor connectivity of internet & V \\
\hline $\mathbf{6}$ & Lack of internet mapping facility & VI \\
\hline $\mathbf{7}$ & Illiteracy of famers & VII \\
\hline $\mathbf{8}$ & Lack of employees and labours & VIII \\
\hline $\mathbf{9}$ & Influence of middlemen on farmers & IX \\
\hline $\mathbf{1 0}$ & Commitment of farmers and traders & X \\
\hline
\end{tabular}

Challenges faced by market committee in online agricultural marketing

Table 7 shows the challenges faced by market committee in online agricultural marketing of dry chilli. The challenges were ranked on basis of scores given by the market committee. Poor farmers participation in online trading of agricultural produce was the major problem followed by limited infrastructure (grading), limited quantity of lots for online marketing. Influence of middlemen on farmers and commitment of farmers and traders were less problematic to market committee. This might be overcome by Govt. taking steps forward in providing proper training, advertisements, campaigns and awareness programs to farmers, traders as well as market officials. 
In conclusion online agricultural marketing was initiated only in six APMCs of North Karnataka on pilot basis. It may be extended to all APMCs in Karnataka. There is a scope for online trading of agricultural commodities in Karnataka. Illiteracy of farmers, misconception and lack of awareness and lack of confidence about e-payment by farmers were the major constraints in online marketing, there is urgent need to create awareness through campaign other extension activities. Regulated markets had lack of skilled employees/staffs for online trading and grading activities. There was an urgent need for capacity building programmes by the state government and other line organizations to train the employees/ staff of APMCs. There is need to institutional support to overcome the challenges of online marketing ultimately which leads to improve the growth of online marketing of agricultural commodities in Karnataka.

\section{References}

Agarwal, N., Sargam, J. and Sudha, N., 2016, The long road to transformation of agricultural markets in India; Lesson from Karnataka. India Gandhi Institute of Development Research, Mumbai publications, 4(3): 1-7

Amratraj, P., 2014, Regulated markets in Karnataka: current status, future needs innovations, challenges and opportunities. M.Sc.(Agri.) Thesis, Univ. Agric. Sci., Dharwad.

Anonymous, 2015, Karnataka state agricultural marketing board

Anonymous, 2016, www.Indiastat.com

Harjot, K. and Daljit, K., 2015, E-commerce in India- challenges and prospects. Int. J. Eng. and Tech., 1(2):36-40

Rahul, G., 2008, Challenges in the adoption of E-commerce in agri-business. Indian J. Agric. sci., 13(7):145-148.

Shivaraja, M. B., 2012, Production and value addition to chilli in northern Karnataka- An economic analysis, M.Sc. (Agri.) Thesis, Univ. Agric. Sci., Dharwad.

Sumitha, T. and Kirubakaran, S., 2014, Eagriculture information management system Int. J. Computer Sci. Mobile Computing, 3(5): 599-607

\section{How to cite this article:}

Pavithra, K. and Mahantesh R. Nayak. 2019. Challenges in Online Marketing of Dry Chilli in Selected APMC of Karnataka, India. Int.J.Curr.Microbiol.App.Sci. 8(01): 456-464. doi: https://doi.org/10.20546/ijcmas.2019.801.048 